\title{
JOVENS POBRES E OS SENTIDOS ATRIBUÍDOS À EDUCAÇÃO ESCOLAR E AO MUNDO DO TRABALHO
}

\author{
Vinicius Oliveira Seabra Guimaräes \\ Pontifícia Universidade Católica de Goiás (PUCGO), Goiânia, Goiás, \\ Brasil
}

\begin{abstract}
REsumo: O presente artigo tem como objetivo geral apresentar os resultados de uma pesquisa empírica realizada com jovens pobres evadidos da escola, residentes no Setor Buriti Sereno, em Aparecida de Goiânia, Goiás, Brasil, destacando suas percepções acerca da categoria juventude, mundo do trabalho e sobre a própria condição de evadidos da escola. Parte-se do seguinte problema: quais as memórias, as trajetórias escolares e as perspectivas de futuro de quatro jovens pobres residentes em um bairro da periferia de Aparecida de Goiânia? Conclui-se que os jovens do Setor Buriti Sereno vivem, em suas condições objetivas, uma limitação social a eles imposta como construção histórica e fruto de uma intencional segregação urbana, que se dá pelas vias do trabalho informal e da evasão escolar.
\end{abstract}

Palavras-chave: Jovens. Periferia Urbana. Escolarização. Mundo do Trabalho.

INTRODUÇÃO

O presente artigo é um dos resultados parciais do grupo de Pesquisa Juventude e Educação, da Pós-Graduação em Educação da Pontifícia Universidade Católica de Goiás. $O$ texto é fundamentado na perspectiva histórico-dialética e relacional, considerando o movimento inserido na história como fator determinante nas relações cotidianas dos agentes em seus espaços e territórios sociais. Pretende-se analisar os fatores socioculturais e históricos inseridos na trajetória de vida de quatro jovens evadidos da escola, com idades entre dezoito e dezenove anos, residentes na $3^{a}$ etapa do Setor Buriti Sereno, na cidade de Aparecida de Goiânia, Goiás, Brasil. A amostragem teve como critério norteador os seguintes aspectos: territorialidade urbana, condição social, evasão escolar e faixa etária.

Busca-se, então, analisar os sentidos atribuídos por um grupo de jovens residentes em um bairro da periferia de Aparecida de Goiânia sobre o processo de escolarização e sua relação com o mundo do trabalho. Além disso, o estudo tem por objetivo analisar o processo de segregação socioespacial das populações das periferias urbanas; investigar a condição juvenil no mundo contemporâneo e sua relação com o processo de segregação socioespacial; e compreender a relação entre segregação socioespacial, processos de escolarização e perspectivas de futuro dos jovens pobres.

O presente estudo recorre a diversos autores que estudam a condição social e a condição juvenil no tempo presente, entre eles destacamos: Bourdieu (2007), Castel 
(1998), Telles (2001), Dayrell (2005), Duarte (2012), Carrano (2002) e Pais (2003). A escolha desses teóricos se deve ao fato de eles serem referência na abordagem que entrelaça pobreza e juventude.

O texto está divido em três partes. Na primeira parte faz-se uma análise da categoria juventude e suas representações a partir das percepções dos próprios jovens investigados. Na segunda parte faz-se uma abordagem acerca de como o mundo do trabalho se insere na vida dos jovens das periferias urbanas. Na terceira parte faz-se uma leitura da função escolar junto aos jovens pobres, destacando a evasão escolar como um construto da condição histórico-social dos jovens das classes populares.

\section{A CATEGORIA JUVENTUDE E OS JOVENS PESQUISADOS}

A ONU celebrou, em 1985, o Ano Mundial da Juventude. Ao longo daquele ano foram realizadas atividades em torno da temática juventude. $O$ principal evento foi o Congresso Mundial Sobre La Juventud, realizado em Barcelona, Espanha, de 8 a 15 de julho. Nesse ano, por força da resolução $n^{\circ} 40 / 14$ e reafirmado pela resolução $n^{\circ} 50 / 81$ de 1995, a ONU estabeleceu que jovens são aqueles que têm faixa etária entre quinze e vinte e quatro anos.

Segundo Hermann (2011), essa faixa etária é a mesma utilizada pela Organização Mundial da Saúde (OMS) e pela Pesquisa Nacional por Amostra de Domicílios (PNAD/IBGE). Bourdieu (2007a) também se vale dessa mesma classificação etária (15-24 anos) na obra $A$ Distinção. Entretanto, ele critica os sistemas de classificações vigentes, principalmente o etário. Isso fica notório em uma entrevista que ele concedeu em 1978 que, posteriormente, em 1983, foi adaptada para a forma de livro, especificamente no capítulo intitulado $A$ "juventude" é só uma palavra. $O$ autor pondera que:

Os cortes em classes de idades, ou em gerações, são tão variáveis e são uma parada em jogo de manipulações [...] O que quero lembrar é muito simplesmente que a juventude e a velhice não são dadas mas construídas socialmente, na luta entre jovens e velhos (BOURDIEU, 2003, p. 152).

De acordo com o autor, a noção de adolescência, juventude e velhice é uma construção social que delimita fronteiras sociais invisíveis entre si. Para o autor, o propósito final dessa categorização etária é desenhar uma divisão de poder e controle social. Portanto, a definição de juventude traz consigo efetivas implicações simbólicas, variando de acordo com as representações sociais, expectativas e intentos de uma determinada sociedade. Posto isso, o conceito de juventude não pode ser atrelado apenas à faixa etária, pois extrapola tal delimitação.

Segundo Cassab (2001), Pais (2003), Martins (2004), Dayrell (2005), Garcia (2009) e Duarte (2012), não há um consenso acerca da definição e delimitação da categoria juventude, pois o termo evoca tanto uma condição quanto uma representação social, além de margear fatores cronológicos de faixa etária. Então, em cada momento histórico, em cada cultura, em cada sociedade, se reinterpreta o que vem a ser jovem. 
Devido à multiplicidade de percepções tão distintas entre si e em razão das condições objetivas de ser jovem, o apropriado seria usar o termo juventudes, no plural, segundo Carrano (2002), Pais (2003), Dayrell (2005) e Mendes (2011). Essa forma plural possibilita as variáveis de contradições, limitações e percepções existentes entre os jovens. Sendo assim, as juventudes, numa concepção contemporânea, não são entendidas como um bloco homogêneo, mas, sim, como um mosaico, que desvela a heterogeneidade e a mutabilidade da sociedade atual.

Os próprios jovens, ao darem sentido à sua condição juvenil, levam em consideração suas trajetórias de vida, suas percepções provenientes de sua condição sociocultural e margeiam impressões expostas pela mídia, conforme se observa nos discursos dos jovens pesquisados (nomes fictícios), como segue:

Para mim ser jovem é a pessoa ser alegre, ser extrovertida. Para mim ser jovem não tem idade, para mim qualquer um é jovem independente da idade, é isto aí, amar a todos, ser muito feliz, de bem com a vida, para mim ser jovem é isto. Eu me considero jovem porque eu ainda sou novinha, mas apesar de que eu acho que idade não importa, mas pra mim, eu sou jovem. Sou uma pessoa muito espontânea, muito divertida. (Entrevista, Júlia).

Eu sou jovem sim (pausa). Ser jovem é... (pausa) muita zueira, bagunça, festa, drogas. Ser jovem hoje é não querer nada com nada, só divertir. Bagunça! (Entrevista, Gilney).

Na percepção de Júlia e Gilney, a categoria juventude não tem associação fixa com faixa etária, mas, sim, com a forma de viver e com o trato das relações sociais. Isso reforça os pressupostos apresentados por Martins (2004) e reitera a categoria juventude como construção social, conforme defende Bourdieu (2003). Entretanto, é válido ponderar que o conceito de juventude apresentado pelas jovens é regado de um perceptível romantismo acerca da condição juvenil.

De acordo com Queiroz (2008b), a noção de juventude enquanto "momento preparatório para a vida adulta" (p. 69) traz consigo oportunidades de descomprometimento, tempo livre e despreocupações. Contudo, para a autora, esses distintivos são peculiares a classes abastadas, que têm condições de custear essa liberdade. Há, ainda, que se ponderar que o tempo livre, nas classes populares, é mediado por representações simbólicas de vagabundagem (CASTEL, 1998) e criminalidade (TELLES, 2001), forçando os membros dessas classes, ao se contraporem a estes estereótipos, a estrangularem qualquer possibilidade de extravasamento juvenil, assumindo assim diversas responsabilidades que são antagônicas à própria concepção dos agentes, de juventude como uma fase de liberdade, conforme relatos:

Ser jovem para mim é sair muito, não ter muita responsabilidade, não se preocupar muito, estudar bastante. Porque o jovem tem sempre que estudar. Eu me considero um pouco jovem, não muito porque agora eu tenho responsabilidade em casa, cuidar da minha família, trabalhar bastante. Acho que eu me considero mais adulto do que jovem, porque eu trabalho muito agora, já sustento a minha casa, já pago as minhas contas, então, eu não me considero muito jovem não, me considero mais adulto [...]. (Entrevista, Marcos). 
Eu acho que sou jovem. Ser jovem é divertir muito, mas hoje tenho que trabalhar, porque ficar sem dinheiro não dá, mas aí não dá para divertir muito, só no fim de semana. Tenho que trabalhar. (Entrevista, Ricardo).

Fica evidente que, para o jovem Marcos, a classificação juventude não se aplica por razão de faixa etária, mas, sim, a partir das representações sociais e de atitudes caracterizadas pelo descomprometimento. Nesse caso, na opinião dele, juventude está associada à liberdade e transitoriedade. Para Marcos e Ricardo, o que distingue um jovem de um adulto é a capacidade de assumir responsabilidades, que se traduz de forma objetiva na inserção deles no mercado de trabalho, ainda que informal, por ter que cuidar da família e nas relações de consumo. Mesmo se considerando jovens, esses agentes se contradizem ao definir que não praticam em seu cotidiano ações típicas da juventude, mas sim do mundo dos adultos.

Na concepção desses jovens, a condição juvenil se limita e é sufocada a partir da condição de trabalhador. Ao que parece, para esses jovens, a noção de juventude é negada pela inserção deles no mercado de trabalho, furtando-lhes o divertimento, a casualidade, a alegria e o desprendimento. Neste viés, o tempo de condição juvenil é reduzido por causa do trabalho, por causa das responsabilidades e por causa das expectativas sociais agora depositadas sobre esses jovens-adultos.

\section{OS JOVENS PESQUISADOS E O MUNDO DO TRABALHO}

A inserção prematura dos jovens no mercado de trabalho se dá, segundo Queiroz (2008a), porque os filhos dos trabalhadores aprendem muito cedo a necessidade de contribuírem para a renda familiar e para a própria subsistência. Segundo a autora, isso, em determinado momento, pode até favorecer o processo de solidariedade entre os entes da família. Contudo, Salama e Destremau (1999) ponderam que esse processo de inserção no mundo do trabalho não é espontâneo, mas, sim, condicionado à realidade social em que se vive, culminando rapidamente num conflito entre trabalho e escola, no qual, segundo os autores, a escola quase sempre perde.

Os jovens entrevistados relatam os motivos que os levaram a se inserir de forma precoce no mundo do trabalho, demonstrando, especialmente, a precarização que caracteriza sua condição de jovem trabalhador:

Hoje estou fazendo um bico ali na horta. [Mas você não trabalha na horta todos os dias. Trabalha com o que normalmente?] Pintura (pintor). [Você gosta desta área?] Sim. [É nisto que você quer trabalhar o resto da sua vida?] Não. [O que você quer fazer no futuro?] Quero ser mecânico. [...] [Por que você começou a trabalhar como pintor?] Meu pai morreu há dez anos, minha mãe teve derrame... então tive que trabalhar. (Entrevista, Marcos).

[Você trabalha?] Sim. [Trabalho informal sem carteira assinada?] É. [Em horta?] Sim. [E como era o trabalho lá?] Bom. [Você acha que o que aprendeu lá é válido para sua vida?] Da horta não pode tirar nada de lá. [...]. (Entrevista, Ricardo). 
[Você começou a trabalhar com quantos anos?] Com quatorze lá no Maranhão. Com a costureira. [Qual o seu maior sonho?] Me formar em Direito. [Por que você gosta do direito?] Meu sonho é tentar fazer um pouco de justiça. Ser uma advogada, uma juíza. (Entrevista, Júlia).

Nos relatos acima, percebe-se a existência de um dualismo, que Duarte (2012) apresenta como esperanças subjetivas e oportunidades objetivas. Segundo o autor, tendo por base os estudos de Bourdieu (2007a), as relações com o mundo do trabalho são condicionadas a partir do capital global, que é a integração entre o capital econômico, o capital cultural e o capital social. Os jovens entrevistados do Setor Buriti Sereno, assim como outros jovens das classes populares, são fortemente limitados pelo capital global, do qual são herdeiros. Assim, embora se encontrem em uma condição de acentuada precarização em suas condições de trabalho, os jovens alimentam sonhos de futuro, não perdem suas esperanças e sua própria humanidade. O que se vê, de forma contundente, nos relatos dos jovens, é que suas necessidades e condições de trabalho lhes roubaram a juventude, que seria um tempo de se formar, de se preparar para o futuro e de liberdade fluida. Os "bicos", a temporalidade do trabalho, a precocidade de suas inserções na vida produtiva, a necessidade de contribuir de forma imediata com a renda da família, tudo isso leva esses jovens a se inserirem em uma realidade que a cada dia os explora e tira suas possibilidades de construção consistente de seus futuros, embora alimentem vários desejos quanto ao futuro incerto.

Os jovens pesquisados têm poucas oportunidades de emprego no bairro em que residem, por isso a opção mais concreta é fazer "bico" nas hortas da região. No bairro há três hortas e, em 2015, os jovens recebiam, em média, $\mathrm{R} \$ 40,00$ reais por dia; alguns recebiam $\mathrm{R} \$ 40,00$ reais a mais para colherem verduras na madrugada de domingo. Por ser uma atividade informal, não apresenta constância na frequência das diárias, nem na periodicidade do trabalho. Destaca-se ainda que os jovens que integraram a pesquisa jamais trabalharam de carteira assinada:

Eu comecei a trabalhar, assim, eu nunca trabalhei de carteira assinada na minha vida não, eu já trabalhei sem ser de carteira assinada, [...] eu era muito nova [...] ah! eu quase nem lembro mais. Eu não tenho profissão nenhuma, mas já trabalhei com costura. Trabalhei numa confecção, mas não levei isto a sério não. (Entrevista, Júlia). Emprego fixo nunca tive, até hoje eu não tenho emprego fixo, nunca trabalhei num emprego fixo, sempre foi bico mesmo, trabalhando pros outros. Nunca fui de perder o emprego assim não, quando o emprego acabava ou quando eu saí porque o patrão era ruim pra pagar, alguma coisa assim, mas chegar a perder o emprego nunca perdi não. Já trabalhei na horta, já trabalhei como ajudante de pedreiro, já trabalhei de ajudante de azulejista, já trabalhei de pintura, trabalhei mais em construção civil. Trabalhei também mais meu tio, ajudando a fazer próteses dentárias. Acho que só. (Entrevista, Marcos).

Eu nunca trabalhei de carteira não, mas faço bico na horta e outra coisa que aparecer. (Entrevista, Ricardo).

Carteira assinada nunca tive não. Mas tô sempre trabalhando de alguma coisa, ajudando meu irmão na pintura ou outra coisa que der. (Entrevista, Gilney). 
Conforme os relatos acima, é possível concordar com Garcia (2009), ao considerar que os jovens no contexto urbano, especialmente os jovens pobres, são inseridos no mundo do trabalho em "ocupações não valorizadas socialmente" (p. 228), com flexibilização e precarização da jornada de trabalho, recebendo baixos salários, percepção igualmente partilhada por Antunes (2005). Contudo, os jovens investigados não demonstram constrangimento de expor que trabalham na horta, o que se deve, provavelmente, ao fato de ser este um trabalho legitimador da condição de trabalhador, que traz distinção entre os jovens do Setor Buriti Sereno.

Essa interpretação vai ao encontro do que afirma Rizzini (1997): "os pobres que se situavam mais acima na escala de moralidade eram aqueles que trabalhavam" (p. 90). A autora descreve isso fazendo alusão ao século $X X$; ainda hoje, porém, tal perspectiva permanece aplicável. Desta forma, o trabalho para as juventudes pobres rompe a barreira econômica e agrega sentidos morais, sociais e culturais. Posto isso, o desemprego também sofre alterações na sua condição estrutural, pois a situação de desemprego, na percepção dos jovens, traduz-se em um impedimento de participação social efetiva e, então, assume um sentido de inadequação. Essa perspectiva do trabalho em seu caráter de distinção e moralizante é reforçada pelos próprios jovens, como se observa nas falas deles:

Eu acho que ser jovem trabalhador é muito bom, você já vai adquirindo uma experiência mais na frente, é melhor que estar na rua fazendo coisa errada. (Entrevista, Júlia).

O que eu penso de ser jovem já ser trabalhador porque é bom, me trouxe mais responsabilidade. Acho que eu não tenho muita brincadeira assim levo muito as coisas a sério. Acho que o trabalho na minha juventude foi muito bom porque me tirou do crime, me tirou das drogas, não saio para festa, baladas assim [...] o sentido do trabalho para mim é sempre não deixar minha família passar dificuldade [...] o trabalho na minha vida é muito bom, se faltar serviço para mim falta tudo em casa. (Entrevista, Marcos).

Jovem tem que trabalhar, precisa de dinheiro. E isto é bom. Não fica à toa por aí (Entrevista, Ricardo).

Jovem que trabalha é bom sim, pois já vai aprendendo uma profissão e não fica fazendo coisa errada. (Entrevista, Gilney).

Os relatos dos jovens reafirmam o papel social e moralizador que o trabalho tem para as classes populares. Ele vem para suprir uma evidente necessidade financeira, mas, ao mesmo tempo, demonstra também uma adequação aos padrões classificatórios e de controle social previamente estabelecidos pela sociedade. Ser jovem trabalhador, para os jovens que compõem esta pesquisa, é tanto uma questão de sobrevivência quanto de alinhamento às expectativas sociais sobre eles depositadas.

Segundo Pais (1991), para os jovens, a condição de desempregado representa a "perda da sua identidade" (p. 974). Para o autor, o termo identidade representa as conexões das práticas sociais dos indivíduos, que os tornam integrados em uma comunidade por meio do sentimento de pertença social. No caso dos jovens investigados, conforme relatos descritos anteriormente, o trabalho é entendido como percurso de 
reafirmação da identidade social, ainda que esse trabalho seja de caráter informal e de baixa remuneração. $O$ trabalho representa valor social e os integra, ainda que precariamente, ao mundo dos adultos.

\section{OS SENTIDOS ATRIBUÍDOS À ESCOLA PELOS JOVENS PESQUISADOS}

Entendemos que a escolarização para os jovens pobres de periferia se desvela como a ponta de um iceberg, ficando submersa a estrutura sólida de uma realidade de pauperismo, conforme descrita até o momento. Por conseguinte, as trajetórias escolares dos jovens das classes populares são, corriqueiramente, marcadas por descontinuidades, como será observado nos relatos dos jovens, o que, para Bourdieu (1997), configura uma realidade preocupante, pois, "pela falta de capital cultural, estão votados a um fracasso escolar praticamente certo" (p. 220).

A fim de compreender a relevância da escola na trajetória de vida dos jovens investigados, fizemos um recorte, conforme segue, contemplando o tempo escolar dos jovens antes da efetiva evasão. Os relatos a seguir trazem um pouco das percepções que os jovens têm da escola e seus agentes:

Bom...sobre a minha escola, quando eu tava na infância eu me diverti muito. Estudar, não estudei muito não, não prestava atenção muito nas aulas, nem nas professoras, não dava ouvido a quase nada [...] Na adolescência eu fugia muito da escola, faltava muito às aula, daí eu comecei a me afastar muito. Algum momento importante na minha vida na escola mesmo, eu acho que eu não tive quase nenhum [...] o relacionamento com os professores também era bom, só que eles brigavam muito comigo porque eu faltava, faltava muita aula. Os coordenadores também, nunca tive nenhuma briga, mas eles também, eles nunca me elogiaram, eu também não estudava direito. Dificuldade com alguma matéria eu já tive, em matemática, sempre tive dificuldade na matemática, porque achava difícil fazer conta, nunca me dei bem com números. [...] Eu não gostava de ir pra escola porque (pausa) eu achava muito, (pausa), muito tedioso. Não aguentava ficar vendo as aulas todinha. [...] meu pai morreu quando eu recebi a notícia eu estava na escola. [...] a escola me ajudava mais a ser, escrever bem, a ler, a conversar melhor, só que eu porque não dava ouvido, me educava. Só quando a gente cresce um pouquinho que a gente pensa nas coisas que a gente aprendia e nas coisas que fazia de errado. [...] eu esperava terminar meus estudos mais rápido, o que eu esperava não foi alcançado. [...] Depois que meu pai faleceu minha mãe não conseguiu segurar a gente não, foi aí que eu parei de estudar. (Entrevista, Marcos).

A escola quando eu era criança, a escola que eu estudei, ela era boa em vários aspectos, menos na parte estrutural, o governo não cuidava muito bem, era bem esquecida, mas em relação aos estudos sempre foi bom. Eu sempre gostei muito das brincadeiras, participar dos jogos escolares. Nunca gostei mesmo de estudar, sempre tive preguiça nesta parte. Já depois, na minha adolescência eu passei a gostar de outras coisas, comecei a gostar mais das matérias, teve matéria que eu me dei bem que eu não gostava quando era criança. Agora o que eu nunca gostei é que a escola, para mim a escola era um símbolo de você ir pra escola, estudar e aprender, hoje você em dia você vai pra escola e vê coisas erradas, e eu não gostava da turma que eu estudei pois lá eles usava drogas e tudo dentro da sala, e isto me incomodou bastante. O que eu gosto muito de lembrar de minha vida escolar é dos amigos que 
eu fiz, várias amizades boas, uns que eu tenho até hoje, das brincadeiras, foi muito bom pra mim. Eu acho que me ajudaram a evoluir quanto pessoa. Eu sempre fui uma boa aluna, nunca dei trabalho não, sempre fui obediente aos professores, aos diretores, ao pessoal da merenda, nunca tive problemas com isto não. Mas eu nunca gostei mesmo de ir pra escola, parece que, já deixei de ir pra escola por três vezes, deixei de ir. A primeira vez foi porque eu queria trabalhar, aí eu passei dois anos sem ir, e também por questão de preguiça. Já esta vez agora, esta vez agora, que eu parei de estudar, 2015, eu quis trabalhar e também um pouquinho de preguiça também. [...]Na verdade eu parei de estudar por preguiça, mas eu queria trabalhar, tanto que eu trabalhei um pouquinho. [...] eu acho que o fato de eu ter parado de estudar foi uma burrice, foi coisa de adolescente mesmo, não tem explicação, hoje eu sinto falta. Me prejudicou porque pra arrumar trabalho tem que ter o Ensino Médio completo. (Entrevista, Júlia).

Na escola foi bom (pausa), lá não tive muito problemas não. [...] Comecei a estudar com seis anos de idade. Sempre estudei na mesma escola, esta que tem aqui no Setor. Eu me lembro muito dos professores, tinha uns bons outros não, uns tinha paciência, outros não. [...] Eu não gostava do diretor porque ele era muito chato. [...] Não me lembro de ter sofrido nenhum preconceito na escola, tinha bons amigos lá. Agora eu lembro de uma briga que teve lá na escola, pouco antes de eu sair, quase me furaram lá. Eu briguei com um colega meu por causa de um lápis, aí ele levou a briga tão a sério que ele queria matar eu. Aí o único jeito foi sair correndo debaixo das asas do meu pai. [...] acho que não foi bom eu ter parado de estudar não. (Entrevista, Ricardo).

Lá na escola eu só fazia bagunça, estudei não, era bagunça demais, o tempo todo. [...] Eu gostava muito da escola do Parque Amazonas, mas hoje quando eu me lembro, gosto mais desta daqui (referindo à escola do Setor). [...] acabei envolvendo com as pessoas erradas e comecei a faltar demais, aí parei. (Entrevista, Gilney).

A leitura dos relatos do tempo escolar vivido pelos jovens permite aferir que o período de escolarização para eles foi principalmente de cultivo de amizades, pois em todos os relatos há menção da interação com amigos, quer seja pela bagunça ou pela afetividade. Dessa forma, a escola para esses jovens foi um lugar para além do conhecimento acadêmico e se mostrou agente eficaz para integrações sociais e culturais, ainda que eles não se adequassem aos padrões institucionais, o que posteriormente culminou na evasão escolar.

Percebe-se ainda que a noção de amizade permeia todos os discursos e memórias escolares. Há que se destacar que a própria designação para o ato de bagunça evoca algum entrelaçar de amizade, assim como a própria sensação de desgosto por algum agente escolar também denota caráter afetivo. Por essa razão, é possível considerar que a escola para esses jovens ocupou, simbolicamente, um lugar central na construção das relações sociais.

Outro aspecto perceptível, igualmente identificado nos estudos de Abramo (2014), foi o fato de os jovens do presente, ainda que evadidos da escola, conviverem com a contradição de terem mais educação formal que seus pais, porém viverem com maior precariedade e insegurança social. 
É válido lembrar que os jovens investigados, ainda que evadidos da escola, têm mais tempo de escola que os pais, conforme descrito no início deste artigo. Entretanto, essa maior permanência na escola é permeada por uma perceptível autoculpabilização, pois, supostamente, esses jovens tiveram mais chances escolares e de mobilidade social do que os seus pais, porém fracassaram ao evadirem da escola. Tal condição vai ao encontro do que Duarte (2012) já havia identificado em pesquisa realizada junto a jovens de um bairro da periferia de Goiânia. De acordo com o autor, os depoimentos de um grupo de jovens pesquisados

conduzem a uma discussão que nos parece muito importante na educação escolar contemporânea, ou seja, a autoculpabilização dos jovens pelo seu próprio fracasso. Embora, como veremos em depoimentos a seguir, eles identifiquem os limites da escola, a precária promoção da aprendizagem e as dificuldades na relação intergeracional nesse espaço, atribuem a si mesmos a culpa pelo próprio fracasso ( $p$. 143).

O que se percebe ainda é o encontro das afirmações dos jovens desta pesquisa em relação às suas dificuldades de continuidade de sua vida escolar, com as considerações de Duarte (2012) sobre os sentidos atribuídos à educação escolar,

O que se percebe nos depoimentos é a distância da educação escolar em relação ao que poderíamos chamar de atribuição de sentido a esse espaço de socialização. A escola não se mostra atrativa, não compensa os sacrifícios pelos quais têm que passar cotidianamente (p. 143).

Quanto aos relatos dos jovens com relação à indisciplina, o que se constata, a partir das discussões de Duarte (2012), é que, na medida em que a possibilidade de se acumular capital cultural e as trocas que dele decorrem é reduzida, são reduzidas também a necessidade de subordinação dos jovens a um modelo educacional longo, extenuante, enfadonho, que não garante a recompensa esperada. Para esse autor, a escola deveria ser capaz de dialogar com a realidade dos alunos, contribuindo para a formação de sujeitos críticos, capazes de refletir sobre a realidade histórico-social do bairro em que moram. Contudo, segundo o autor, a escola é, contrária e, intencionalmente, o principal agente de manutenção das desigualdades, inculcando nos jovens a obediência e a aceitação, assim como a não identificação com a realidade local.

Duarte (2012) considera que a escola no contexto liberal desempenha um papel ideológico e, por vezes, utópico, em relação à ascensão social das classes populares, ascensão que se daria, supostamente, por consequência direta do mérito e do esforço individual desses jovens, resgatando, assim, a mesma lógica do protagonismo, agora, porém, estabelecida a partir das relações escolares. Tal perspectiva reafirma, mais uma vez, a rota de colisão entre as expectativas subjetivas e as condições objetivas. Segundo o autor, é por essa razão que se estabelece uma dialética perversa, que se desdobra em dois momentos: primeiro, no fracasso escolar dos jovens pobres e, segundo, no movimento de rejeição da escola.

De acordo com Baldino e Cavalcante (2014), "a escolarização de jovens das camadas populares no Brasil é marcada, ainda, por uma trajetória de descontinuidade, em 
razão, prioritariamente, da entrada precoce no mundo do trabalho" (p. 207). Tal perspectiva foi igualmente observável na presente pesquisa, especialmente na fase de entrevistas, quando os jovens foram indagados sobre o porquê de terem abandonado a escola. As respostas foram:

[E por que você parou?] Bagunça! Só fazia bagunça... bagunça demais. Daí me envolvi com as pessoas erradas e acabei faltando muito, até que parei. [Qual a lembrança mais antiga que você tem da escola?] Só lembro da bagunça, bagunça demais. (Entrevista, Gilney).

[E por que você parou de estudar?] Ah... envolvi com as pessoas erradas, drogas, bagunça. [Estas pessoas erradas estão na escola ou fora da escola?] Dentro... e fora. (Entrevista, Marcos).

[O que te fez parar de estudar?] Eu tinha que trabalhar, eu tava sem dinheiro, homem sem dinheiro não presta. (Entrevista, Ricardo).

[Por que você parou de estudar?] por preguiça! (Entrevista, Júlia).

No relato dos jovens acerca da evasão escolar destacam-se três supostas causas: a bagunça, o trabalho e a preguiça. A partir dessas categorias fica novamente evidente uma autoculpabilização, reforçando os pressupostos de Duarte (2012), ao considerar que a educação escolar ofertada junto às comunidades pobres de periferia é impregnada de falácia liberal. Tal sentimento de autoculpabilidade se mostra seja pelo suposto desinteresse que favoreceu a bagunça, seja pela suposta falta de virtude pessoal que culminou na preguiça, seja pela necessidade financeira.

Observa-se nos discursos dos jovens investigados que em nenhum momento eles relacionaram a evasão escolar com a própria escola, ou com a condição histórico-social, ou com a relevância do ensino, ou com qualquer outro fator extrínseco a eles próprios. A percepção que os jovens têm da evasão escolar é que essa é uma escolha individualizada e particularizada, o que, evidentemente, é falacioso, pois a evasão escolar é resultante de inúmeras causas coletivas e de desarranjos na trama social.

A pesquisadora Zaluar (2004), ao investigar a condição do jovem no contexto do Rio de Janeiro, igualmente se surpreende com a quantidade de jovens que atribuem à preguiça o fato de não terem mais interesse em frequentar a escola, à semelhança das respostas dadas por Júlia. A autora também constata que quem mais atribui a si mesmo a desvirtude da preguiça são os jovens pobres, fato que comprova, mais uma vez, o quanto a perspectiva liberal está impregnada no habitus dos jovens pobres, sendo a escola ou, nesse caso, a evasão da escola, produtora de significados e de habitus.

De acordo com Bourdieu (2010), a problemática da diplomação está associada exata e diretamente à condição histórico-social dos sujeitos, então, a percepção de Júlia acerca da ineficácia do curso feito transcende o campo escolar e reflete a sua própria condição social de jovem pobre de periferia. Para o autor, "fora do mercado propriamente escolar, o diploma vale o que, do ponto de vista econômico e social, vale seu detentor" (p. 152). Sendo assim, a escolarização não é capaz de transpor a condição de vida dos jovens investigados para uma realidade destoante daquela que eles vivenciam cotidianamente. 
Para Abramo (2014), os jovens vivenciam mais insegurança com relação ao mundo do trabalho por não conseguirem relacionar os conhecimentos escolares com a prática laboral. Esse fato é igualmente perceptível nos relatos dos jovens desta pesquisa:

[Você acha que a escola tem alguma coisa para contribuir para a sua vida pessoal?] Sim. As coisas boas e ruins que aconteceram, isso serve de exemplo. [...] [ Você acha que trabalho e estudo tem alguma relação, você acha que estudar mais ganha mais?] Eu acho que não tem muita relação não. Estudar mais ganhar mais. Acho que vai da pessoa (Entrevista, Júlia).

O que eu aprendi na escola não me ajudou muito no trabalho não [...] o meu trabalho não exige muita escolaridade não, acho que por isto eu me dei bem (Entrevista, Marcos).

[Você acha que o que você aprendeu na escola te serve no trabalho?] Sim. Não. Não no trabalho que faço hoje, mas para eu conseguir um trabalho melhor tenho que estudar (Entrevista, Gilney).

[O que você aprendeu na escola te serve pro trabalho?] Não. Na horta não precisa disto não (Entrevista, Ricardo).

Fica evidente que, para os jovens, a relevância da escola não se dá numa relação direta com o mundo do trabalho, até porque o universo laboral conhecido por eles é o informal e o de atividades braçais. Retomando a fala da Júlia, há nela uma expressão que merece atenção, quando ela diz: "acho que vai da pessoa". Tal construção traz consigo uma carga conceitual de protagonismo e individualismo, pressupostos que descortinam a função da escola no cenário neoliberal.

Para Dias e Guimarães (2007), a escola para os jovens pobres é uma "estratégia de sobrevivência" e se constitui num "conjunto de crenças imaginárias" (p. 130) como espaço de mobilidade social. Segundo Bourdieu (1997), a escola para as famílias pobres é "uma espécie de terra prometida, sempre igual no horizonte, que recua à medida que nos aproximamos dela" (p. 483).

Segundo Bourdieu (2007b), há uma distância significativa entre as expectativas subjetivas e as condições objetivas. No caso dos jovens do Setor Buriti Sereno, essa lógica se observa na intenção profissional que eles almejavam a partir da formação escolar, na real inserção desses jovens no mercado de trabalho, na herança profissional/escolar dos pais, na relação/expectativa escolar e, especialmente, nas reais condições histórico-sociais inerentes de ser morador de uma periferia urbana.

Os jovens que compõem a pesquisa são jovens evadidos da escola, o que torna mais distante da realidade objetiva 0 discurso deles de ascensão profissional, especialmente se essa trajetória for por meio da via de diplomação escolar. Por essa razão, para Castel (2008), "a maioria dos jovens tem os pés na precariedade econômica e a cabeça no universo cultural das classes médias" (p. 39).

Para Duarte (2014), o atual modelo de ensino consegue, no máximo, favorecer a imitação, numa "pretensa mimese" dos padrões de vida estampados nas etiquetas na sociedade moderna. Sendo assim, o autor pondera que a má qualidade das escolas públicas de periferias é uma intencional manutenção da discriminação social. Em relação a isso, o autor é enfático ao afirmar que a inexistência de oportunidades de estudo é fator de discriminação, mas "estar na escola e não aprender devidamente é também fator de sujeição e discriminação" (p. 88). 
De acordo com Castel (2008), os jovens não estão na condição de excluídos, pois estão parcialmente dentro e parcialmente fora da sociedade e de seus agentes socializadores, a exemplo da escola. E é essa condição de desfiliação que faz os jovens se revoltarem, segundo o autor, pois têm "convicção de estar diante de um futuro sem perspectivas, desprovidos de recursos para serem reconhecidos como membros por inteiro da sociedade" (p. 40). No caso dos jovens do Setor Buriti Sereno, as revoltas contra essa condição de desfiliação se dão claramente no ambiente escolar sob a expressão "bagunça" - citada inúmeras vezes nas entrevistas, questionários e relatos.

O que se pode constatar, após a interação com os jovens do Setor Buriti Sereno, é que, para eles, a escola exerce uma função de mantenedora da expectativa subjetiva de ascensão social e profissional, supostamente garantindo-lhes um futuro melhor, especificamente com condições financeiras melhores. Por mais que nos discursos feitos pelos jovens haja uma dissociação entre o trabalho atualmente realizado por eles e a escolarização recebida, esses mesmos jovens depositam na escola, contraditoriamente, a esperança de um futuro distante de suas próprias trajetórias.

A escola, na perspectiva sob a qual foi observada, torna-se um agente social capaz de gerar expectativas subjetivas nos alunos, impondo-lhes valores de uma cultura dominante e também ofertando-lhes um suposto futuro dissociado de sua própria cultura. $O$ resultado iminente é a frustração de quem, ao perceber as condições objetivas de ser jovem de periferia, vê-se fragmentado, sem sua própria história, por uma violência simbólica e estrutural, porém legitimada pela escola.

\section{CONSIDERAÇÕES FINAIS}

Ao analisar a trajetória de vida dos jovens e seus discursos sobre a escola, percebemos que, ainda que a escolarização não tenha representado efetivamente um conhecimento útil para a vida cotidiana desses agentes, contraditoriamente os mesmos jovens depositam suas esperanças futuras quase que exclusivamente na escola. Tal postura demonstra que a escola ainda ocupa papel fundamental na inserção social dos jovens de periferia, mesmo que tal importância se dê, efetivamente, no interior de uma visão muito subjetiva, destituída das condições objetivas.

Ao buscarmos perceber a relação das mudanças no mundo do trabalho com as condições de vida das classes populares, constatamos que os pobres são os mais prejudicados na lógica da precarização e da acumulação flexível do tempo presente, submetendo os trabalhadores e filhos de trabalhadores a essa lógica, não por escolha, mas por se constituírem nos únicos postos de trabalho disponíveis a eles, em consequência de suas condições objetivas enquanto pobres habitantes das periferias urbanas e do processo de discriminação social e cultural imputada a esses agentes.

O ser jovem nessa condição coloca o desafio de conviver com as precariedades da vida cotidiana impostas aos agentes pobres residentes nas periferias urbanas e, ao mesmo tempo, viver uma fase da vida em que a sociedade contemporânea promete como um segundo tempo de preparação para o enfrentamento da vida adulta. Promete-se ainda uma liberdade e um tempo de fruição que são incompatíveis com as condições 
objetivas desses agentes. Nesse sentido, tal noção de juventude passa a ser uma falácia, na medida em que os jovens da periferia são submetidos ao trabalho precoce, à falta de espaços de cultura e lazer, a territórios marcados pela violência urbana, e a um modelo educacional que não contribui de forma efetiva para o seu desenvolvimento humano e social.

O que se pode constatar ainda é que os jovens pobres da periferia são inculcados a assumirem uma culpa pelo seu próprio fracasso, sob o argumento de que são preguiçosos, baderneiros, violentos, sem ambições para o futuro, apáticos e que não dão o devido valor à educação escolar. Atribui-se a esses sujeitos uma suposta falta de importância à educação escolar, como se o sentido atribuído à escolarização fosse construído pelos próprios estudantes desde o início de sua escolarização e não pela própria sociedade em seu conjunto, em especial quando se trata da escolarização destinada às maiorias.

Por fim, este estudo nos possibilita compreender que há muito a se estudar em torno das culturas juvenis, em especial em se tratando de jovens pobres da periferia, tendo em vista a sua complexidade e urgência de abordagens mais verticalizadas. Há, portanto, a necessidade de se analisar de forma dialética as relações entre o global e o local, entre os elementos de uma cultura juvenil, que podemos considerar como sendo comum no mundo ocidental do tempo presente, e as especificidades vivenciadas pelos agentes em territorialidades específicas.

Artigo recebido em: 04/10/2018 Aprovado para publicação em: 05/12/2018

\section{YOUNG PEOPLE AND THE SENSES ATTRIBUTED TO SCHOOL EDUCATION AND THE WORLD OF WORK}

ABSTRACT: The present article has as general objective to present the results of an empirical research carried out with poor youngsters evaded from the school, living in the Buriti Sereno Sector, in Aparecida de Goiânia, Goiás, Brazil. Highlighting their perceptions about the youth category, the world of work and the very condition of school dropouts. Part of the following problem: What are the memories, the trajectories and future prospects of four poor young people living in a suburb of Aparecida de Goiânia? It is concluded that the young people of the Buriti Sereno Sector live, under their objective conditions, a social limitation imposed on them as a historical construction and the result of an intentional urban segregation, which occurs through informal work and school dropout.

KEYWORDS: Young people. Urban Periphery. Schooling. World of Work.

JÓVENES POBRES Y LOS SENTIDOS ATRIBUIDOS A LA EDUCACIÓN ESCOLAR Y AL MUNDO DEL TRABAJO

RESUMEN: El presente artículo tiene como objetivo general presentar los resultados de una investigación empírica realizada con jóvenes pobres evadidos de la escuela, residentes en el Sector Buriti Sereno, en Aparecida de Goiânia, Goiás, Brasil. Destacando sus percepciones acerca de la categoría juventud, mundo del trabajo y la propia condición de evadidos de la escuela. Se parte del siguiente 
problema: ¿Cuáles son las memorias, las trayectorias escolares y las perspectivas de futuro de cuatro jóvenes pobres residentes en un barrio de la periferia de Aparecida de Goiânia? Se concluye que los jóvenes del Sector Buriti Sereno viven, en sus condiciones objetivas, una limitación social a ellos impuesta como construcción histórica y fruto de una intencional segregación urbana, que se da por las vías del trabajo informal y de la evasión escolar.

PALABRAS CLAVE: EJA. Jóvenes. Periferia Urbana. Escolarización. El mundo del trabajo.

\section{REFERÊNCIAS}

ABRAMO, Helena Wendel [org]. Estação juventude: conceitos fundamentais - pontos de partida para uma reflexão sobre políticas públicas de juventude. Brasília: Secretaria Nacional de Juventude, 2014.

ANTUNES, Ricardo. Adeus ao trabalho? Ensaio sobre as metamorfoses e centralidade do mundo do trabalho. 10a ed. São Paulo: Cortez, 2005.

BALDINO, José Maria e CAVALCANTE, Cláudia Valente. Reconfiguração da educação superior brasileira, jovens e política de cotas sociais e raciais: o que preconizam as metas e estratégias do projeto de PNE 2011-202. Revista Educativa. Pontifícia Universidade Católica de Goiás (PUC-GO), Goiânia, v. 17, n. 1, pp. 201-222, jan/jun. 2014.

BOURDIEU, Pierre et alii. A miséria do mundo. Petrópolis, RJ: 1997.

BOURDIEU, Pierre. A distinção. Critica social do julgamento. 6 ed. São Paulo: EDUSP; Porto Alegre: Zouc, 2007a.

BOURDIEU, Pierre. A economia das trocas simbólicas. $6^{\mathrm{a}}$ ed. São Paulo: Perspectiva, 2007b.

BOURDIEU, Pierre. Escritos de educação. 11 ed. Rio de Janeiro: Vozes, 2010.

BOURDIEU, Pierre. Questões de Sociologia. Lisboa: Fim de Tempo, 2003.

BRASIL. Estatuto da Criança e do Adolescente. Lei $n^{\circ}$ 8.069, de 13 de julho. Brasília: Imprensa Nacional, 1990.

CARRANO, Paulo Cesar Rodrigues. Os jovens e a cidade. Rio de Janeiro: Relume Dumará, 2002.

CASSAB, Maria Aparecida Tardin. Jovens pobres e o futuro-A construção da subjetividade na instabilidade e incerteza. Niterói: Intertexto, 2001.

CASTEL, Robert. A discriminação negativa: cidadãos ou autóctones? Petrópolis, RJ: Vozes, 2008.

CASTEL, Robert. As metamorfoses da questão social: uma crônica do salário. Petrópolis: Vozes, 1998. 
GUIMARÃES, V. O. S

DAYRELL, Juarez. A Música entra em cena: o rap e o funk na socialização da juventude. Belo Horizonte: UFMG, 2005.

DIAS, Luciana Campos e GUIMARÃES, Maria Tereza Canezin Estratégias de sobrevivência de jovens pobres urbanos usuários de programas educativos. In: SPOSITO, Marilia Pontes (org). Espaços públicos e tempos juvenis: um estudo de ações do poder público em cidades de regiões metropolitanas brasileiras. São Paulo: Global, 2007.

DUARTE, Aldimar Jacinto. A educação escolar e os processos de enfrentamento da realidade urbana por jovens da periferia. Revista Educativa. Pontifícia Universidade Católica de Goiás (PUC-GO), Goiânia, v. 17, n. 1, pp. 75-92, jan/jun. 2014.

DUARTE, Aldimar Jacinto. Jovens urbanos da periferia de Goiânia: Espaços Formativos e Mediações Escolares. 2012. 216 f. Tese (Doutorado em Educação) - Universidade Federal de Goiás, 2012.

GARCIA, Dirce Maria Falcone. Juventude em tempo de incertezas: enfrentando desafios na educação e no trabalho. São Paulo: Annablume, 2009.

HERMANN, Michael. Jovens tardios. Breves reflexões sobre adolescência e juventude. Salvador: Clube de Autores/agbooks, 2011.

MARTINS, Wilmont de Moura. Trilhas juvenis. uma análise das práticas espaciais dos jovens em Goiânia. 2004. 134 f. Dissertação (Mestrado em Geografia) - Universidade Federal de Goiás, Goiânia, 2004.

MENDES, Gardene Leão De Castro. O discurso da criminalização da Juventude no Jornal Daqui. 2011. 147 f. Dissertação (Mestrado em Educação) - Pontifícia Universidade Católica de Goiás, Goiânia, 2011.

PAIS, José Machado. Culturas juvenis. 2 ed. Lisboa: Imprensa Nacional, 2003.

PAIS, José Machado. Emprego juvenil e mudança social: velhas teses, novos modos de vida. Revista Análise Social. Universidade de Lisboa, Lisboa, v. XXVI, n. 114, pp. 945-987. 1991.

QUEIROZ, Edna Mendonça Oliveira de. Jovens trabalhadores e a escola noturna. In: GUIMARÃES, Maria Tereza Canezin (org). Estudos sobre jovens e processos educativos na contemporaneidade. Goiânia: Editora da UCG, 2008a.

QUEIROZ, Edna Mendonça Oliveira de. Mediação familiar em processo: formação de jovens estudantes do ensino superior. 2008. 165 f. Tese (Doutorado em Educação) Universidade Federal de Goiás, 2008b.

RIZZINI, Irene. O século perdido: raízes históricas das políticas públicas para a infância no Brasil. Rio de Janeiro: Editora Universitária Santa Úrsula, 1997.

SALAMA, Pierre; DESTREMAU, Blandine. O tamanho da pobreza - economia política da distribuição de renda. Rio de Janeiro: Garamond, 1999.

TELLES, Vera da Silva. Pobreza e cidadania. São Paulo: USP, 2001. 
ZALUAR, Alba. Integração perversa: pobreza e tráfico de drogas. São Paulo: Editora FGV, 2004.

Vinicius Olivelra Seabra Guimarães: Doutorando em Educação pela Pontifícia Universidade Católica de Goiás (PUC Goiás) - linha de pesquisa: Educação, Sociedade e Cultura.

ORCID: https://orcid.org/0000-0003-0690-9357

E-mail:vs.seabra@gmail.com

Este periódico utiliza a licença Creative Commons Attribution 3.0, para periódicos de acesso aberto (Open Archives Iniciative - OAI). 